\title{
FUNGSI KEPALA SEKOLAH DALAM MENCIPTAKAN IKLIM KERJA
}

\author{
Bradley Setiyadi ${ }^{1}$, Moni Lukita ${ }^{2}$ \\ Program Studi Administrasi Pendidikan, FKIP Universitas Jambi ${ }^{1,2}$ \\ Email korespondensi: bradleysetiyadi@unja.ac.id ${ }^{1}$
}

\begin{abstract}
Abstrak
Tujuan penelitian ini untuk mengetahui bagaimana pimpinan mengambil keputusan dalam menciptakan iklim kerja, pimpinan memberikan perhatian terhadap guru dan staf dalam menciptakan iklim kerja di SMPN 22 Kota Jambi, dan apa saja kendala pimpinan. Penelitian ini dilatar belakangi bahwa kepala sekolah belum sepenuhnya memperhatikan kinerja guru dan staf sehingga belum mencapai keberhasilan iklim kerja yang kondusif. Penelitian ini menggunakan metode pendekatan deskriptif kualitatif dengan jenis penelitian studi kasus (case study). Subjek penelitian adalah kepala sekolah, wakil kepala sekolah, guru, kepala tata usaha, dan staf tata usaha. Teknik yang digunakan dalam penelitian ini adalah Purposive Sampling yaitu pengambilan sampel dengan menetapkan ciriciri khusus yang sesuai dengan tujuan penelitian. Teknik pengumpulan data dalam penelitian ini menggunakan metode observasi, wawancara, dan dokumen. Teknik analisis data yang digunakan adalah reduksi data, penyajian data, dan penarikan kesimpulan. Hasil penelitian menunjukkan bahwa kepala sekolah mengambil langkah yang tepat dalam pengambilan keputusan serta memberikan perhatian kepada guru dan staf dalam meningkatkan iklim kerja.
\end{abstract}

Kata Kunci : fungsi kepala sekolah, iklim kerja

\begin{abstract}
The purpose of this research is to find out how leaders make decisions in creating a working climate and pay attention to teachers and staff in creating a working climate at SMPN 22 Kota Jambi, as well as the leadership's obstacles. This research is based on the fact that the principal has not fully paid attention to the performance of teachers and staff so that he has not achieved a successful conducive working climate. This study used a qualitative descriptive approach to the type of case study research. The research subjects were the principal, vice-principal, teacher, head of administration, and administrative staff. The technique used in this research was purposive sampling by determining specific characteristics in accordance with the research objectives. Data collection techniques in this study were observation, interviews, and documents. The data analysis techniques used were data reduction, data presentation, and conclusion drawing. The results showed that the principal took the right steps in making decisions and paid attention to teachers and staff in improving the work climate.
\end{abstract}

Key Words : the function of the principal, working climate

\section{PENDAHULUAN}

Keberhasilan suatu manajemen khususnya pada lembaga pendidikan sangat tergantung kepada kepala sekolah yang memimpin dimana kepala sekolah harus memiliki keahlian untuk mengelola segala sumber daya yang ada di sekolah terutama sumber daya manusia, mampu membawa lembaga tersebut guna meraih tujuan yang telah ditentukan sekolah serta bisa dimanfaatkan serta didayagunakan secara optimal. Peraturan Menteri Pendidikan Nasional Republik Indonesia Nomor 13 Tahun 2007 Tentang Standar Kepala Sekolah/Madrasah menyatakan bahwa kepala sekolah wajib mencakup tentang kompetensi sosial, kewirausahan, kepribadian, supervisi serta kompetensi manajerial. Sebagai pemimpin kepala sekolah juga harus dapat memenuhi kelima standar kompetensi tersebut yang terintegrasi dalam kinerja kepala sekolah [1].

Kepala sekolah yang berhasil adalah mereka yang memahami keberadaan sekolah, serta bertanggung jawab dan mampu melaksanakan fungsinya sebagai kepala sekolah untuk memimpin sekolah. Terkait peningkatan kinerja tentang fungsi 
kepala sekolah pada masing-masing lembaga pendidikan yang berbeda. dimana kepala sekolah harus mampu berfungsi sebagai EMASLEC yaitu, Educator (pendidik), Manager (pengelola), Administrator (pengadministrasi), Supervisor (pengawas), Leader (pemimpin), Enterpreneur (pengusaha), dan Climate creator (pencipta iklim) [2].

Oleh karena itu, sebagai pemimpin pendidikan pada tingkat satuan pendidikan, kepala sekolah memiliki tanggungjawab dan wewenang terhadap berkembangnya suatu sekolah yang dipimpin. Kepala sekolah mengupayakan untuk mempunyai berbagai kemampuan, di mana kemampuan yang berkaitan dengan manajemen ataupun kepemimpinannya, tujuannya untuk memajukan dan mengembangkan sekolah tersebut baik secara produktif, mandiri, efektif, akuntabel dan efisien. Dalam kondisi tersebut ada tuntutan berbagai beban pekerjaan yang akan dikerjakan para tenaga pendidik yang mengacu kepada tugas, pokok, fungsi, dan perannya dari masing-masing.

Iklim kerja adalah suatu keadaan atau suasana lingkungan di dalam organisasi yang dapat dirasakan, dilihat dan dipikirkan secara langsung maupun tidak langsung oleh para staf/karyawan, yang dapat tercipta dari hubungan antar pribadi, baik secara vertikal, ataupun secara horizontal.

Fungsi kepemipinan kepala sekolah merupakan hal yang sangat penting dalam menciptakan iklim kerja yang kondusif bagi guru karena iklim kerja yang kondusif memberikan kontribusi terhadap peningkatan hubungan interpersonal dan kinerja organisasi antar guru maupun staf dan warga sekolah lainnya [3]. Iklim kerja terdiri atas keamanan kerja, motivasi untuk berkinerja baik, hubungan yang baik antar rekan kerja, keamanan kepada karyawan, pengakuan atas kinerja yang baik serta partisipasi dalam proses pengambilan keputusan [4].

Penelitian ini diharapkan dapat bermanfaat untuk menentukan bagaimana fungsi kepemimpinan kepala sekolah dalam menciptakan iklim kerja, menemukan alternatif solusi-solusi melalui fungsi kepemimpinan kepala sekolah, dan faktor pendukung dan penghambat dari fungsi kepemimpinan kepala sekolah dalam menciptakan iklim kerja.

\section{METODE}

Pendekatan yang digunakan dalam penelitian ini yaitu menggunakan pendekatan deskriptif kualitatif dengan jenis penelitian studi kasus (case study).

Data Primer dalam penelitian ini yaitu data wawancara, dan observasi mengenai fungsi kepala sekolah dalam menciptakan iklim kerja kondusif dan menyenangkan di SMP Negeri 22 Kota Jambi. Data sekunder yaitu data-data yang dijaring di SMP Negeri 22 Kota Jambi yang meliputi: (1) Histori dan geografis, (2) Keadaan lingkungan, (3) Keadaan sarana dan prasarana, (4) Keadaan guru, dan staf, (5) Struktur organisasi SMP Negeri 22 Kota Jambi.

Sumber data dalam penelitian adalah subjek dari mana data dapat diperoleh. Dalam penelitian ini penulis menggunakan dua sumber data : (a) Sumber data primer, Adapun yang menjadi sumber data primer dalam penelitian ini adalah kepala sekolah, wakil kepala sekolah, guru, kepala tata usaha, dan staf di SMP Negeri 22 Kota Jambi. (b) Sumber data sekunder, yaitu data yang langsung dikumpulkan oleh peneliti sebagai penunjang dari sumber pertama. Dapat juga dikatakan data yang tersusun dalam bentuk dokumen-dokumen. Pada penelitian ini, peneliti menggunakan sumber data sekunder berupa dokumen pendukung, dan catatan peristiwa atau 
kejadian penting, atau pihak-pihak yang berkepentingan yang terkait dalam pengumpulan data mengenai fungsi kepala sekolah dalam menciptakan iklim kerja di SMP Negeri 22 Kota Jambi.

Dalam penelitian ini teknik pengumpulan data yang utama adalah observasi, wawancara dan studi dokumen. Observasi dalam penelitian ini peneliti menggunakan observasi terfokus yaitu suatu observasi yang telah difokuskan dan dipersempit pada aspek-aspek tertentu terkait dengan fungsi kepala sekloah dalam menciptakan iklim kerja di SMP Negeri 22 Kota Jambi.

Wawancara dilakukan untuk melengkapi data berupa: 1) Bagaimana pimpinan mengambil keputusan dalam menciptakan iklim kerja di SMPN 22 Kota Jambi. 2) Bagaimana pimpinan memberikan perhatian terhadap guru dan staf dalam menciptakan iklim kerja di SMPN 22 Kota Jambi. 3) Apa saja kendala pimpinan dalam menciptakan iklim kerja dalam hal pengambilan keputusan dan perhatian terhadap guru dan staf di SMPN 22 Kota Jambi. Dokumen dalam penelitian ini merupakan teknik pengumpulan data penelitian yang mengumpulkan data berupa catatan-catatan, foto, video dan lainnya. Guna mendapatkan catatan penting yang terkait tentang bagaimana fungsi kepala sekolah dalam menciptakan iklim kerja dalam hal pengambilan keputusan dan pimpinan memberikan perhatian kepada guru dan staf. Serta apa kendala pimpinan dalam menciptakan iklim kerja dalam hal pengambilan keputusan dan perhatian terhadap guru dan staf di SMPN 22 Kota Jambi.

Analisis data wawancara (kualitatif) dalam penelitian ini dianalisis dengan menggunakan teknis analisis yang meliputi (1) reduksi data, (2) penyajian data, (3) penarikan kesimpulan dan verifikasi [5].

\section{HASIL DAN PEMBAHASAN}

Berdasarkan observasi awal di SMP Negeri 22 Kota Jambi, iklim kerja yang ada masih kurang kondusif. Hal ini terlihat dari suasana bahwa masih ada yang datang terlambat dan guru maupun staf tata usaha yang keluar saat jam sekolah berlangsung, kepala sekolah belum sepenuhnya memperhatikan kinerja guru dan staf, sehingga belum mencapai keberhasilan iklim kerja yang kondusif. Dalam hal pengambilan keputusan, kepala sekolah melibatkan guru dan staf dan mempertimbangkan pendapat dari guru, staf dan pihak lain yang terlibat dalam masalah tersebut, tetapi dalam pengambilan keputusan masih ada yang tidak ikut serta dalam rapat seperti guru yang sudah lama di sekolah tersebut atau yang sudah senior. Sedangkan mengenai perhatian terhadap guru dan staf berdasarkan indikator keberhasilan iklim kerja yang kondusif adalah seluruh komponen sekolah mampu bekerja sama dan saling mendukung hal ini merupakan salah satu aspek penting untuk mendorong keberhasilan kinerja yang baik oleh guru dan stafnya akan tetapi di SMP Negeri 22 Kota Jambi kinerja guru dan staf belum maksimal.

Dari hasil wawancara dan observasi yang dilakukan di SMP Negeri 22 Kota Jambi terkait dengan pengambilan keputusan dapat diketahui bahwa kepala sekolah dalam mengambil keputusan melibatkan guru-guru dan staf, kepala sekolah SMP Negeri 22 Kota Jambi dalam pengambilan keputusan yang dilakukan melihat apa yang menjadi pertimbangan sebelum membuat keputusan seperti bagaimana permasalahannya, siapa yang terlibat hingga manfaat serta dampak dari keputusan yang diambil tersebut. Dalam pengambilan keputusan selalu dirapatkan agar keputusan yang ditetapkan dapat berjalan dengan maksimal dan tidak memberikan dampak negatif untuk sekolah 
ke depannya. Selanjutnya, keputusan yang diambil oleh kepala sekolah dilakukan secara musyawarah sesuai dengan ketentuan yang ada, meskipun semua sudah diatur berdasarkan tupoksi guru dan staf tetapi perlu adanya komunikasi dan koordinasi agar tidak terjadi permasalahan yang menghambat tugas pokok dan fungsi di sekolah. Karena komunikasi dan koordinasi merupakan peran penting dalam menciptakan iklim kerja di sekolah serta dalam pencapaian visi dan misi sekolah.

Hal ini dikarenakan kepala sekolah harus memiliki visi, misi, kreatif serta inovatif dan berorientasi pada mutu. Strategi ini merupakan usaha sistematik kepala sekolah secara terus menerus untuk memperbaiki kualitas layanan sehingga fokusnya diarahkan pada guru dan tenaga kependidikan lainnya agar lembaga kependidikan yang dipimpinnya dapat berjalan dengan baik. Sebagai pimpinan sekaligus supervisor di sekolah, peran dan tanggung jawab kepala sekolah sangat strategis dalam meningkatkan kinerja guru maupun tenaga kependidikan lainnya [6]. Kepemimpinan kepala sekolah yang baik ditunjukkan dari kemampuan kepala sekolah dalam menjelaskan tugasnya sebagai pengawas secara baik, selain itu kepala sekolah juga telah memiliki stabilitas emosi saat menghadapi setiap masalah yang timbul, memiliki kemampuan dalam mengambil setiap keputusan secara tegas, memiliki keterampilan komunikasi yang baik, dan memiliki keterampilan menjalin hubungan sosial dengan guru secara baik pula [7]. Di tangan kepala sekolah peningkatan mutu sekolah bisa tercapai, karena kepala sekolah sebagai seorang pemimpin memiliki peranan untuk dapat mengkoordinir semua personil di sekolah untuk dapat menjalankan tugasnya secara lebih optimal. Kekuatan kepemimpinan kepala sekolah menghasilkan berbagai kebijakan dan operasionalisasi kerja yang dibimbing oleh visi yang akan dijadikan dasar pencapaian tujuan sekolah. Visi yang dijalankan secara konsisten harus menuntut perubahan iklim yang lebih berorientasi pada efektivitas sekolah. Dengan demikian hal penting yang memposisikan diri sebagai komponen yang memberikan pengaruh yang kuat pada efektivitas pencapaian pendidikan yang berkualitas di era desentralisasi adalah Visionary Leadership [8].

Gaya pengambilan keputusan yang dilakukan oleh Kepala Sekolah SMPN 22 Kota Jambi termasuk gaya konseptual dimana pembuat keputusan gaya konseptual dalam memecahkan masalah mereka akan memiliki pandangan yang luas dan suka mempertimbangkan banyak pilihan dan kemungkinan di masa yang akan datang. Pembuat keputusan ini, akan membahas sesuatu dengan orang sebanyak mungkin, untuk mendapat sejumlah informasi [9].

Dari hasil wawancara dan observasi yang dilakukan di SMP Negeri 22 Kota Jambi kepala sekolah terlebih dahulu memperhatikan karakter dari masingmasing guru maupun staf di sekolah, sehingga dapat mengetahui bagaminana cara untuk melakukan pendekatan, memberikan perhatian kepada guru dan staf dan bagimana cara yang tepat untuk memberi motivasi dalam menciptakan pelayanan dan lingkungan kerja yang kondusif. Dalam memberikan perhatian terhadap guru dan staf kepala sekolah mengikutsertakan guru maupun staf tata usaha dalam pelatihan ataupun seminar, untuk menambah wawasan dan meningkatkan kinerja. Pada lingkungan sekolah, kepala sekolah mengajak seluruh warga sekolah untuk melakukan kegiatan bersama dengan asas kekeluargaan, melakukan pengontrolan di lingkungan sekolah dengan melakukan pengarahan dan 
pendekatan kepada staf dan guru, melalui rapat rutin, takziah bersama, pengajian bersama, kalau sakit dijenguk dan disantuni, sharing dan lain-lain kepada guru, staf dan semua pihak yang terlibat di dalam lingkungan sekolah. Sehingga dengan adanya hubungan yang baik, dan harmonis antara warga sekolah guru, staf serta kepala sekolah, dapat menciptakan hubungan yang saling menghormati, dan menjalankan tugas pokok masing-masing tentu akan saling mendukung kinerja guru maupun staf serta tercipta iklim kerja yang kondusif. Hal ini bertujuan untuk membangun kerjasama dan menjaga keharmonisan warga sekolah. Warga sekolah diharapkan untuk terus taat terhadap setiap peraturan, seperti itu juga dalam menciptakan iklim kerja yang positif guru dan staf saling pengertian, disiplin, transparan, toleransi, tanggungjawab, memiliki kebersamaan, dan menciptakan aturan yang baik.

Iklim kerja dapat menjadi kekuatan yang besar dalam mempengaruhi perilaku guru dan staf. Iklim kerja sangat berperan terhadap keberhasilan dalam melaksanakan pekerjaan, karena setiap orang akan dapat bekerja dengan baik jika iklim atau suasana yang ada di lingkungannya memberikan kenyamanan, perasaan tenang, aman dan merasa dihargai. Suasana kerja yang baik dan menyenangkan akan mendorong guru dan staf untuk bekerja dengan penuh tanggungjawab. Sebaliknya, iklim kerja kurang menyenangkan dapat menurunkan prestasi kerja guru [10]. Kepemimpinan kepala sekolah mempunyai pengaruh yang positif atau negatif dengan kinerja guru, hal ini akan berpengaruh terhadap proses kegiatan belajar-mengajar di sekolah. Iklim organisasi mempunyai pengaruh yang positif atau negatif dengan kinerja guru akan dipengaruhi personil di sekolah. Pengaruh yang dimaksud meliputi pengaruh antar guru dengan kepala sekolah, guru dengan guru, personil sekolah dengan guru, guru dengan siswa, maupun dengan orang tua siswa [11]. Iklim kerja sekolah sebagai serangkaian sifat lingkungan kerja yang dinilai langsung atau tidak langsung oleh guru dan staf, yang dianggap menjadi kekuatan utama dalam mempengaruhi kinerja guru dan staf, yang membentuk harapan dan perasaan seluruh guru dan staf sehingga kinerja guru dan staf meningkat [12].

Berdasarkan hasil penelitian di SMP Negeri 22 Kota Jambi terkait dengan kendala pimpinan dalam menciptakan iklim kerja dalam hal pengambilan keputusan dan perhatian terhadap guru dan staf dapat dilihat dari paparan berikut: Kendala pimpinan dalam menciptakan iklim kerja dalam hal pengambilan keputusan dan perhatian terhadap guru dan staf yaitu adanya guru yang datang tidak tepat waktu, tidak ikut serta dalam rapat, masih ada yang titip absen dan keluar saat jam sekolah berlangsung. Ketika ada kegiatan di sekolah semua dilibatkan untuk mempererat hubungan antara seluruh warga sekolah tujuannya untuk mengetahui pribadi maupun karakter dari masingmasing individu, sehingga tidak ada lagi yang berkelompok antara kelompok satu dengan kelompok lain di lingkungan sekolah. Kepala sekolah mendukung serta mendorong program-program yang ada kepada setiap warga sekolah demi terwujudnya tujuan serta visi, misi sekolah. Setiap sekolah memiliki persoalan yang berbeda dengan sekolah yang lain, demikian juga setiap kepala sekolah menghadapi hambatan dalam melaksanakan tugas kepemimpinannya. Salah satu upaya yang dilakukan kepala sekolah dalam menghilangkan hambatan tersebut adalah dengan menjalin hubungan personal yang baik dengan semua guru dan tenaga kependidikan lainnya. Dengan hubungan dekat, maka kepala sekolah dapat mengetahui karakteristik tiap guru 
serta dapat mengambil akar permasalahan yang dihadapi [13].

Kepala sekolah harus mampu menjalankan tugas dan fungsinya dengan memimpin secara autokratif dengan gaya pengambilan keputusan yang direktif, sekaligus harus mampu juga membangun komunikasi yang intensif dengan bawahan, memahami situasi, kondisi, dan karakter individu bawahannya supaya tidak tercipta jarak yang terlalu jauh antara bawahan dan atasan. Pengendalian diri seorang kepala sekolah dalam menghadapi setiap masalah juga sangat penting, supaya bawahan tidak merasa tertekan dan terpaksa dalam menjalankan tugas-tugasnya di sekolah [14]. Kepala sekolah diharapkan mampu berperan sesuai dengan tugas, wewenang, dan tanggung jawabnya. Kepala sekolah diharapkan dapat berperan sebagai manajer dan pemimpin yang efektif. Sebagai manajer, kepala sekolah diharapkan mampu mengatur semua potensi sekolah agar dapat berfungsi secara optimal. Hal ini dapat dilakukan jika kepala sekolah mampu melaksanakan fungsi-fungsi manajemen dengan baik, yaitu terkait dengan perencanaan, pengorganisasian, pelaksanaan, dan pengawasan [15].

\section{SIMPULAN}

Berdasarkan hasil penelitian dan pembahasan, dapat ditarik kesimpulan sebagai berikut:

1. Pimpinan mengambil keputusan dalam menciptakan iklim kerja di SMP Negeri 22 Kota Jambi sudah melakukan langkah yang tepat. Dalam mengambil keputusan kepala sekolah melibatkan guru-guru dan staf di sekolah, melihat apa yang menjadi pertimbangan sebelum membuat keputusan seperti bagaimana permasalahannya, siapa yang terlibat hingga manfaat serta dampak dari keputusan yang diambil tersebut. Selanjutnya keputusan yang diambil oleh kepala sekolah dilakukan secara musyawarah sesuai dengan ketentuan yang ada, diatur berdasarkan tupoksi guru dan staf, serta adanya komunikasi dan koordinasi sebelum membuat keputusan. Karena komunikasi dan koordinasi merupakan peran penting dalam menciptakan iklim kerja di sekolah serta dalam pencapaian visi dan misi sekolah.

2. Pimpinan memberikan perhatian terhadap guru dan staf dalam menciptakan iklim kerja di SMP Negeri 22 Kota Jambi sudah terlaksana dengan baik. Dalam memberikan perhatian terhadap guru dan staf kepala sekolah mengikut sertakan guru maupun staf tata usaha dalam pelatihan ataupun seminar, untuk menambah wawasan dan meningkatkan kinerja guru dan staf. Pada lingkungan sekolah kepala melakukan kegiatan bersama dengan asas kekeluargaan, melakukan pengontrolan di lingkungan sekolah dengan melakukan pengarahan dan pendekatan kepada staf dan guru, melalui rapat rutin, peringatan hari besar di sekolah, takziah bersama, pengajian bersama, jika sakit dijenguk dan disantuni, sharing dan lain-lain kepada guru, staf dan semua pihak yang terlibat di dalam lingkungan sekolah.

3. Kendala pimpinan dalam menciptakan iklim kerja dalam hal pengambilan keputusan dan perhatian terhadap guru dan staf yaitu masih ada guru yang datang terlambat dan tidak ikut serta dalam rapat, masih ada yang titip absen dan keluar saat jam sekolah berlangsung. Serta adanya kesenjangan antar guru, dan staf yang lalai terhadap tugasnya.

\section{DAFTAR PUSTAKA}

$\begin{array}{llrr}\text { [1] } & \text { Peraturan } & \text { Menteri } & \text { Pendidikan } \\ \text { Nasional } & \text { Nomor 13 } & \text { Tahun 2007 } \\ \text { tentang } & \text { Standar } & \text { Kepala } \\ \text { Sekolah/Madrasah. } & & \end{array}$


[2] Peraturan Menteri Pendidikan dan Kebudayaan Nomor 6 Tahun 2018 tentang Penugasan Guru sebagai Kepala Sekolah.

[3] P. F. Sholihah, D. Santoso \& J. Widodo. "Peranan Kepala Sekolah dalam Menciptakan Iklim Kerja Kondisuf bagi Guru di SMA Negeri 5 Surakarta Tahun 2017/2018". Jurnal Informasi dan Komunikasi Administrasi Perkantoran, vol. 2, no. 5, pp. 25-39, 2018.

[4] A. Raziq \& R. Maubalakks. "Impact of Working Environment on Job Satisfaction". Procedia Economics and Finance 23, pp. 717-725, 2015.

[5] Sugiyono. Metode Penelitian Pendidikan: Pendekatan Kuantitatif, Kualitatif dan $R \& D$. Bandung: Alfabeta, 2014.

[6] Mukhtar. "Strategi Kepala Sekolah dalam Meningkatkan Kinerja Guru pada SMP Negeri di Kecamatan Masjid Raya Kabupaten Aceh Besar". Jurnal Magister Admninstrasi Pendidikan, vol. 3, no. 3, pp. 101-117, 2015.

[7] Sonedi. "Pengaruh Kepemimpinan Kepala Sekolah, Iklim Organisasi terhadap Kepuasan Kerja Guru”. Pedagogik Jurnal Pendidikan, vol. 11, no. 2, pp. 134-145, 2016.

[8] S. Karyawati., G. Abdullah \& N. A. N. Muniati. "Pengaruh Kepemimpinan Kepala Sekolah dan Iklim Sekolah terhadap Efefktivitas Sekolah Dasar di Kecamatan Slawi”. Jurnal Manajemen Pendidikan, vol. 6, no. 1, pp. 193-204, 2017.

[9] S. Syafaruddin \& A. Asrul. Manajemen Kepengawasan Pendidikan. Bandung: Cipta Pustaka Media, 2014.
[10] P.P. Lestari \& N. Zuriah. "Pengaruh Kinerja Kepala Sekolah dan Iklim Kerja Guru terhadap Kinerja Guru Teknik Kendaraan Ringan di SMK Negeri Kota Malang”. Jurnal Kebijakan dan Pengembangan Pendidikan, vol. 6, no. 1, pp. 10-21, 2018.

[11] E. Haryani. "Pengaruh Iklim Organisasi Sekolah dan Kepemimpinan Kepala Sekolah terhadap Manajemen Pembelajaran untuk Mewujudkan Kinerja Guru". Jurnal Pendidikan Universitas Garut, vol. 11, no. 01, hal. 77-87, 2017.

[12] Sutianingsih. "Pengaruh Gaya Kepemimpinan Kepala Sekolah dan Iklim Kerja Sekolah terhadap Kinerja Guru”. Jurnal Ilmu Manajemen dan Akutansi Terapan (JIMAT), vol. 7, no. 2, pp. 115-131, 2016.

[13] Muhani., A. Imron dan Kusmintardjo. "Kepemimpinan Kepala Sekolah Dasar di Daerah Terpencil (Studi Multi Kasus di SDN 2 Bakalan dan SDN Kepyar Purwantoro Kabupaten Wonogiri”. Jurnal Pendidikan: Teori, Penelitian dan Pengembangan, vol. 1, no. 8, pp. 1464-1472, 2016.

[14] H. Nai \& W. Wijayanti. "Pelaksanaan Tugas dan Fungsi Kepala Sekolah Menengah Negeri”. Jurnal Akuntabilitas Manajemen Pendidikan, vol. 6, no. 2, pp. 183192, 2018.

[15] Tarhid. "Kepemimpinan Kepala Sekolah dalam Meningkatkan Profesionalisme Guru". Jurnal Kependidikan, vol. 5, no. 2, pp. 141155, 2017. 